A major purpose of the I echnical Information Center is to provide the broadest dissemination possible of information contained in DOE's Research and Development Reports to busines industry, the academic community, and federal, state and local governments.

Although a small portion of this report is not reproducible, it is being made available to expedite the availability of information on the research discussed herein. 
$\mathrm{LAI}-\mathrm{UR}--63-703$

DEß3 009950

TITLE: OPERATING CHARACTERISTICS OF A 2.0-MeV RFQ

AuthoR(S). F. L. rurser, E. A. Wadlinger, 0. R. Sander,

J. M. Potter, and $k$ R. Crandall

submitted to 1983 Particle Accelerator Conference

Pomtions of rus Motige

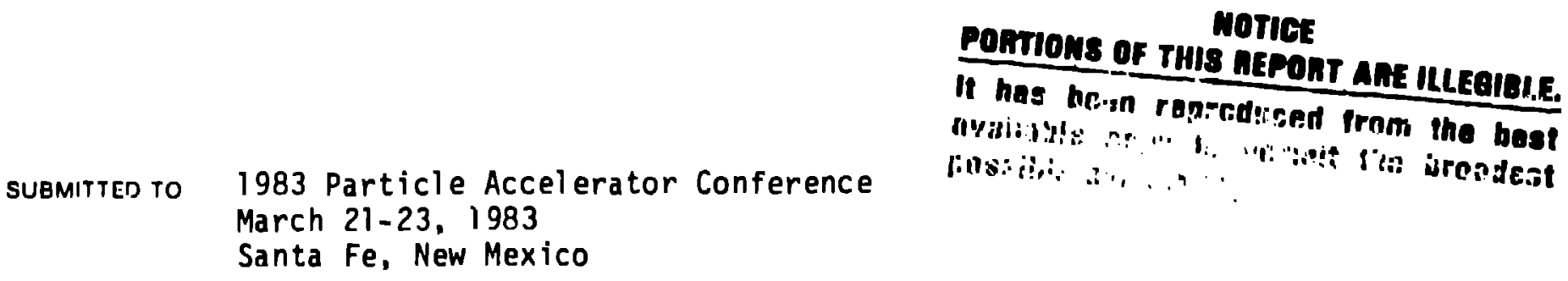

\title{
DISC I.AIMEK
}

\begin{abstract}
This rejout was prepared us an Itciount of work spunsured by an ngency of the Uniled States

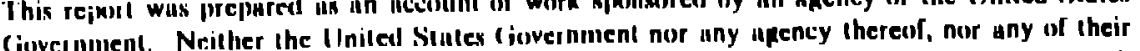

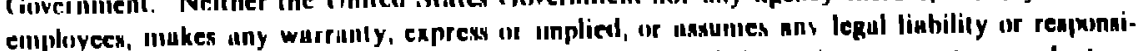
bility for the uceurucy, compleceness, or unefulness of uny inlurmanion, upparalus. product, or bility for the uccurucy, compleleness, or uncfulnesk uf iny informanion, upparalus, prodice, or

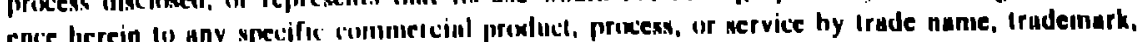

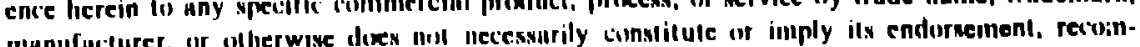

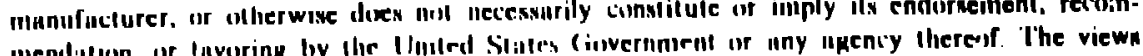

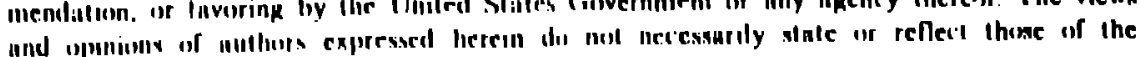

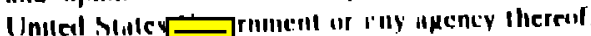

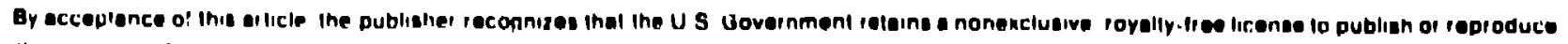
the published lorm ol this conlibution or lo allow others to do 10 , lor 48 Government durposes

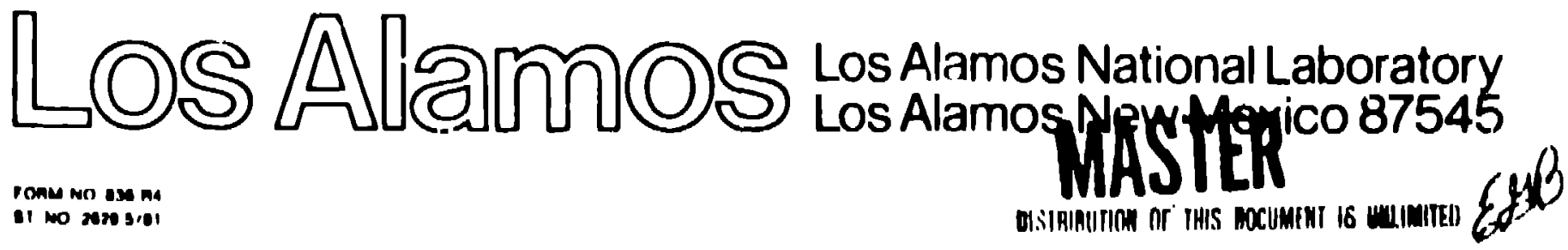


F. O. Purser, E. A. Wadlinger, O. R. Sander, J. M. Potter, and K. R. Crandall, AT-2, MS HB18 Los Alamos National Laboratory, Los Alamos, NM 87545

\section{Summary}

A second radio-frequency quadrupole (RFQ) accelerator has been designed, constructed and operated at Los Alamos National Laboratory. The accelerator's design parameters represent a major extension from the original Los Alamos RFQ, with the new accelerator being 2.5 times as long, having three $t$ Imes the output energy, and with 2.5 times the current $11 \mathrm{~m} / \mathrm{t}$. The reew accelerator's operating characteristics were suddied for 3 months before disassembly to incorporate design modifications. Pesults are discussed.

\section{Introduct ton}

Construction and operation of the new accelerator have led tn increased knowledge and insight into RFO properties in three major areas. The first of these, iivolving $r$ tuning properties of an RFQ structure, is dralt with fully in a paper at this conference ${ }^{2}$ and will be toucherl on here only as the end results affect oneratirin characterisicics. jecond, in the process of coupling $r f$ power into the system, apparenlly idleal ronditions were set up to induce and suppon:t a new PFI voltage breakrown mode that subseguentiy received a considerable amount of study. linally, the ne's accelerator was operated on an e::tensively inclrumented arcelerator lest stand that dllowed its operating chararteristics to be measured arcouralely to serve as a test of the computer prodrins used to bulid design and predtct performance.

\section{Accelerator line couracteristtes}

Ihe (lepilln s,eecif iciations of the RTO are given in idild l. "1" these. the added !ength proved to be a

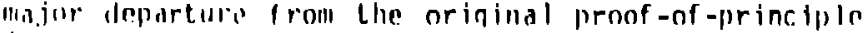
(iv) derign. neter inltial difficultes in tuning the Inodrupole mode to the proper accuraciv, an andly.1. id indicated the sourer of tion problem. Briefly.

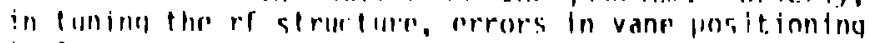

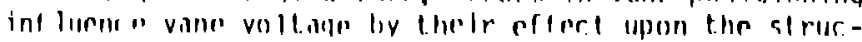

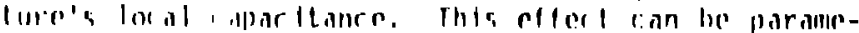
barierl by In. (1).

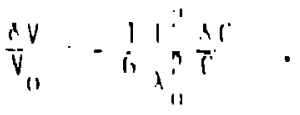

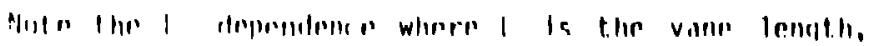

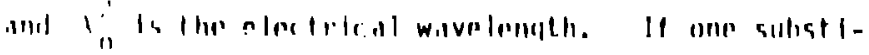

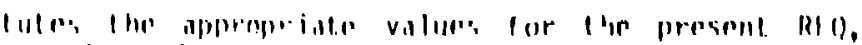

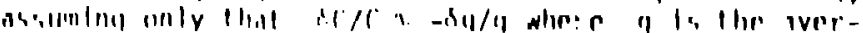

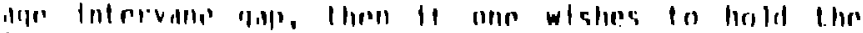

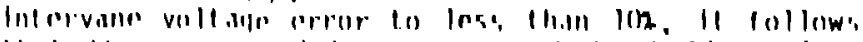

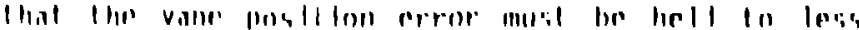

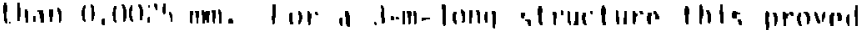

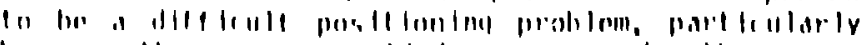

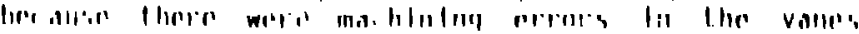

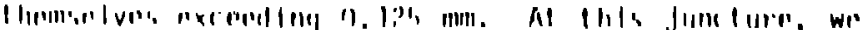

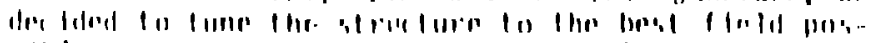
. Hhlo

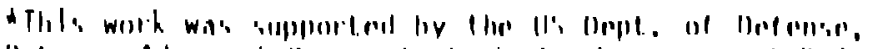

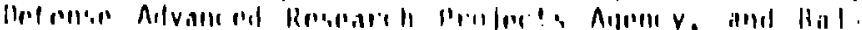

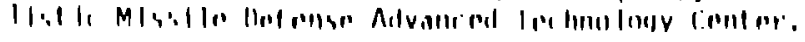

TABLE I

ATS RFQ DESIGN PARAMETERS

$\begin{array}{ll}\text { Frequency } & 425 \mathrm{MHz} \\ \text { Ion } & \mathrm{H}^{-} \\ \text {Number of cells } & 356 \\ \text { Length } & 289.23 \mathrm{~cm} \\ \text { Vane voltage } & 111.34 \mathrm{kV} \\ \text { Averige radius, ro } & 0.394 \mathrm{~cm} \\ \text { Final radius, af } & 0.270 \mathrm{~cm} \\ \text { Final modulation, mf } & 1.830 \\ \text { Inttlal synchronous mhase, } \$ 1 & -90^{\circ} \\ \text { Final synchronous phase, } \phi f & -30^{\circ}\end{array}$

Peak surface field

Nominal current 11 mit Nominal acceptance at $100 \mathrm{~mA}$

$41.4 \mathrm{MV} / \mathrm{m}$ $167 \mathrm{~mA}$ $2.06 \mathrm{Kilpatrick}$ $0.232 \pi \mathrm{cm} \cdot \mathrm{mr}$ (normalized)

the effect of vane voltage errors on operating paranieters. The final longiturinal quadrupole field distributions are shown in Fig. 1. Voltage variations of $2.50 \%$ existed along the structure's length.

\section{ion Arcing}

The arcelerator was Installed on the accelerator test stand and wavequirle coupled to a 1.25 MW klystron power source. In the initicl stuh tuning of the wavenuide, the cavlty was left slightly undercoupled $(B<1.0)$, and a low-0 wavequidn cavity was createrl hy placing the stubs too far froin the winclow, slowing down the time response.

After rf conditioning the accelerator for 1 wh, it was sustaining design nower levils. The system unclerwent a normal $r f$ conditioning with attendant cleamup sparking with no ilfftculty. After thorough rf condltioning, beam was injer:ted into the dricelerator. The beatn Injection triggered a complete rf short ircult; that is, reflected power equaled Inciderl power. Input beal! power as low as $1 \mathrm{pW}$ proved a, reforetive as larger beam curr nts In trlquerlny tolal nower reflectlon. As suon as bean current was interrupted, of bower was restored. Thls hehavior persisted lor rf power levels ranglna from \& W $1.0 \% 700 \mathrm{~kW}$.

Inltlally we susperted electron multelpartorlnit as the souree of the nbserved hehavior, but eventually

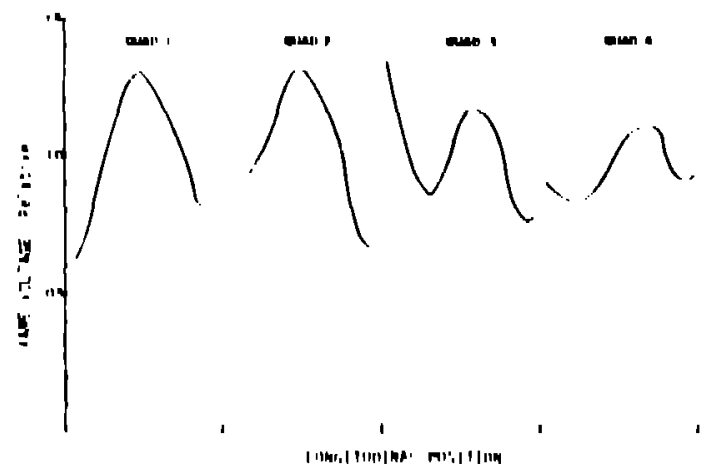

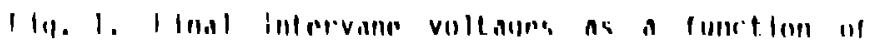

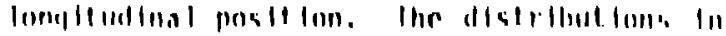

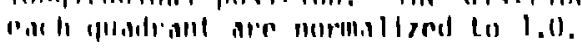


this was ruled out. Voltage and gap lengths at all suspect areas such as the vane to end-tuner gap, coupling slots, and manifold capacitors would not sustain multipactoring at the voltages at which breakdown occurred. Studies of electron orbits for the Intervane gaps themselves indicated a degree of inslabllity that would not support multiplication. In addition, electron multipactoring is a selfsustaining phenomenon that usually does not cease when beam is turned off.

The mechanism that we belleve explatns the breakdowns was proposed by Paul Channell at Los Alamos. His studies of ion orbits in the vane gaps Indicated very stable, self-focusing discharges that could produce siffictent power loss to provide the short circuit causing the observed total power reflections. The ion (in this case, proton) ortits are shown 1, Flg. 2. After being initlated by the beam, these discharges propagate along the entire vane length and eventually self-quench fiom the hydrogen exhaustion of the substrate that produces the prutons for multiplication. In our inftial tune, the power system's time response under loading was inadequate to force this hreakdown to the quench point. Tuning to produce a slightly overcoupled condition eliminated lon arcing as a problem.

\section{QFQ Performance}

The accelerator test stand is equipped with a high brightness, pulsed, negative ion source; ${ }^{3}$ several computerized emittance scanners located both before and after the RFQ; and approprlately suppressed Faraday cups at varlous locations for measuring pulsed beam currents. Its principal defictency at present 15 the absence of a magnetic analyzing system for beam-enerciy analysis.

Both the ton source and the $r f$ power system operate in a pulsed mode. The ion source operates at a $b-11 z$ frequency with pllise lengths varying from 0.5 to $1.25 \mathrm{~ms}$; whereas the if power system was operated with pulse lengths varying from $1.0 \mathrm{~ms}$ down to $0.1 \mathrm{~ms}$, a 150 at $5 \mathrm{~Hz}$. Output bear curments from the ion source ranged from $80-$ to $150-\mathrm{mA}$ peak current, with beam currents injected into the RFO varying from $35.0 \mathrm{~mA}$ down to near zero. Average pulsed-power levels in the $\mathrm{H} / \mathrm{O}$ were varled from $100 \mathrm{~kW}$ to somewhat in

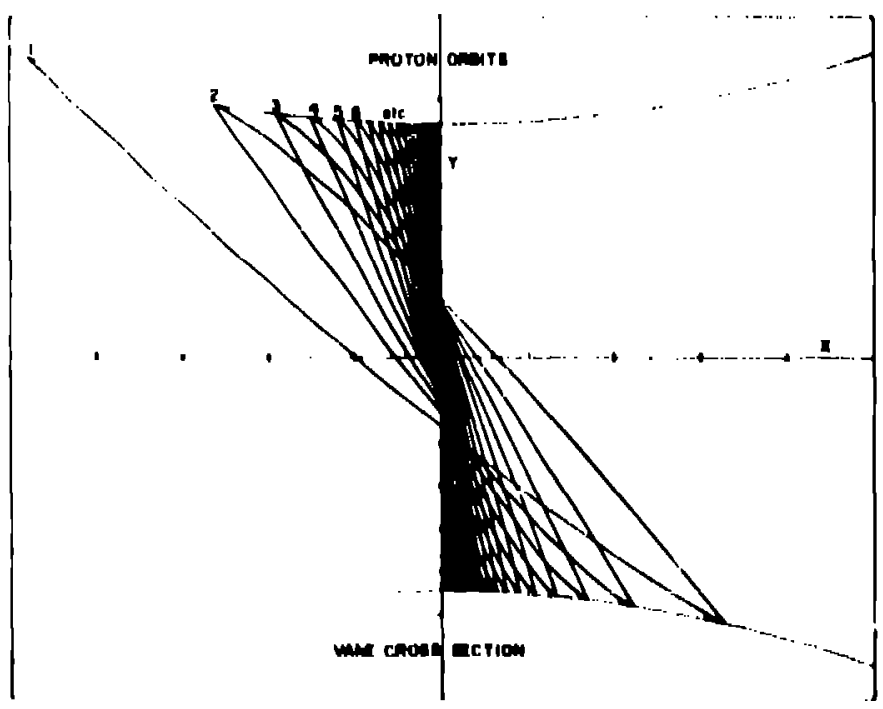

rlil. 'S lomputere plot of the lon trafertorles showInit thele stallilty and that thry collapse rajlelly to the valle conter. Thle view looks alone the Rro axts excess of $650 \mathrm{~kW}$, which may be compared to the destgn power level of $550 \mathrm{~kW}$.

Our experimental program was slanted toward measurements that would permit direct tests of the computer codes used at LoS Alamos to model RFQ performance." Given the RFQ's existing (measured) field distribution and the input emittance ard phasespace orlentation, beam current, and energy, the code PARMTEQ can be used to predict varlous output bean parameters as functions of RFQ power leve:. Of these, we have measured total transmission efficlency, Inout and output ream emittances, and transmitted current above varlous threshold energles. iven without enerjy-spectrum analysis, these latter measurements can be used to confirm the prodicted (by PARMTEQ) energy distributions because of the transmisston characteristics of the retarding foils used in the threshold Faraday cups.

In Flg. 3 the predizted and measured total beam transmission effictencies are plotter. The dashed clirve in the flgure indicates the transmission that would have been expected if the RFQ fields could have been properly tuned. The abscissa in the figure is the ratio of actual RFQ power to the 550-kW design power level. Maximum beain current accelerated by the RFQ thus far has been $18 \mathrm{~mA}$.

rigure 4(a) shows the transintssion curve for one of the energy-retarding foils used in the threshoid Faraday cup as a function of monoenergetic. incldent beam energy. Figure $4(b)$ displays the output beam energy distributions predicted by PARMTEQ for several rf power levels. By convoluting the energy distribution and the foil transmission function, one can obtatn a measurement prediction for the threshold cup for this particular foll. In Fig. 5 we show the results of a serles of such measurements compered to the code predictinns. Although the agreement is not perfert, the results are quite gcod when one considers the sensitivity of the output energy distribution to variations in rf power.

\section{RFO Voltage 'evels}

une of the points of interest in the present meas rements is the voltage..hoidling ability of the PFo linac confiquration. Our original design intervani: coltage was $111.34 \mathrm{kV}$, which resulted in voltage gradients of $41.4 \mathrm{MV} / \mathrm{m}$ or $2.06 \mathrm{t}$ imes the Kllpatricik spark criterions for Jur frequency and geometry. Because of the very innuniform Iongttudina' voltage

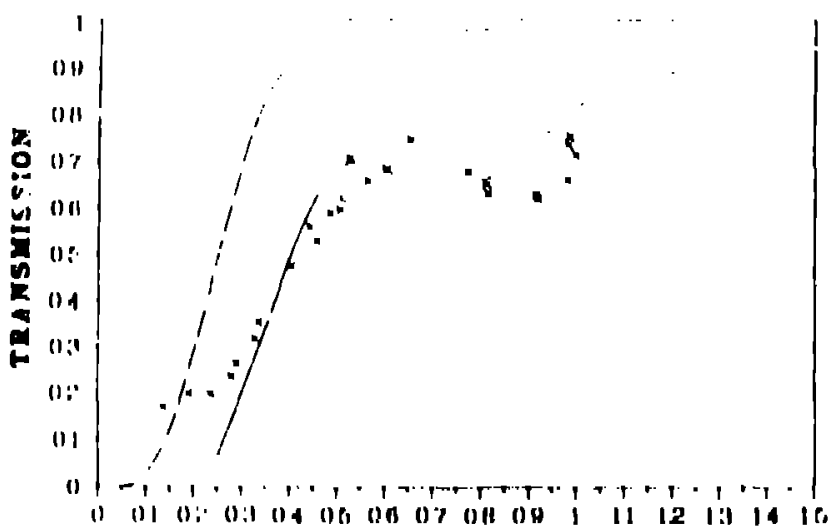

POWBR RATIO

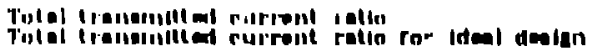

I 1. 3. Calculatod and measured tolal transmlsstun throush the RIO. The dashed curve represent: : he Rro's expected transmlssion if fleld rirors could have been ellminated. 


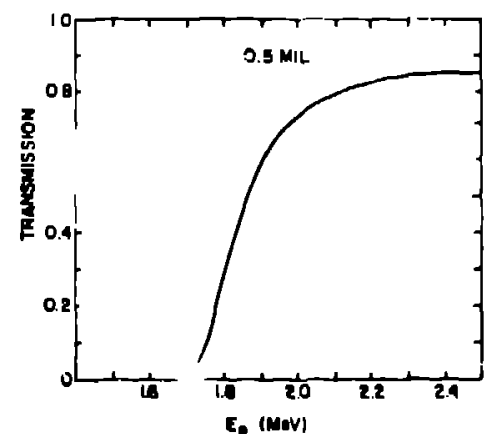

Fig. 4(a). Measured transmission curve for the $0.5-m i l$ retarding foll of the thriacihold Faraday cup.
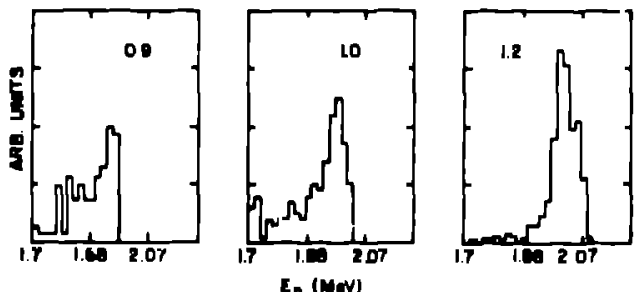

Fig. 4(b). Calculated output energy distributions for the RFQ at powi'r levels of $0.9,1.0$, and 1.? t. Imes the lesign power.

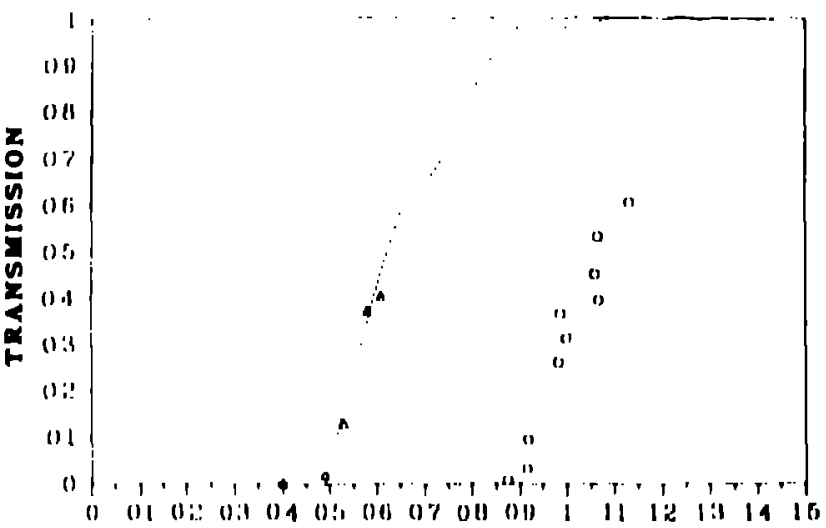

POWBR RAT1O

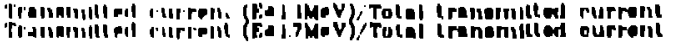

rly. S. Calculatud transmissalons through threshold I aralay culle for hedm enerqter areater than

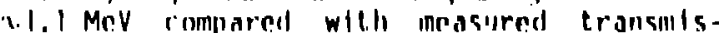
s louls.

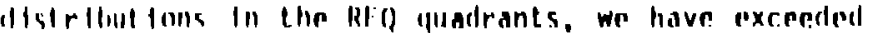

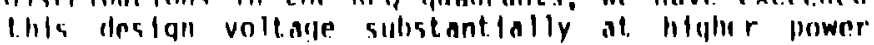
levels. leluure b showe the voltane uradtents in the

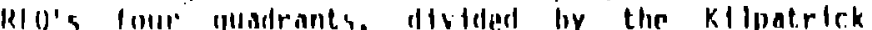
"limit" for the highest. power level at whlch data wire lakmo. Hul exprelence indleates that inaxtimuin sustalualile voltaue lil this conf fouration is somewhat

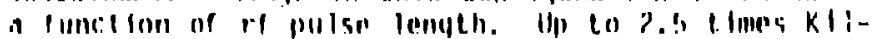
batrick, pulse lenclthe of 1.0 mis or ureater were pos -

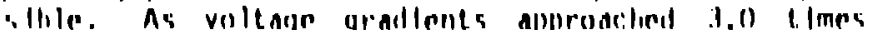
kllpatrlek, sustalnalile pulip inciths uradially shorteneil unt ll at the upper end of wur ranue, oprer-

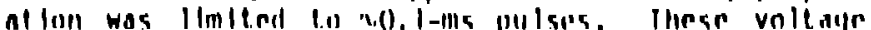
irvels wern sustalind li vacululs that norinally mon-

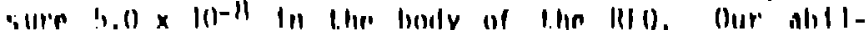

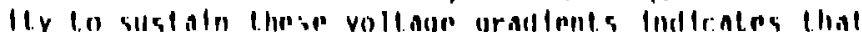

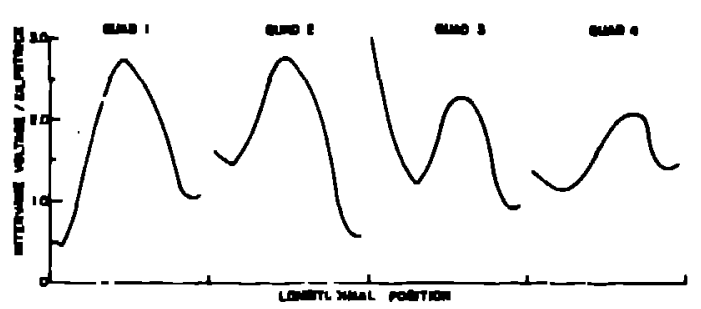

Flg. 6. A near repeat of $F / g, 1$, except that intervane voltages are calculated with $625.0-\mathrm{kW}$ average power in the RFQ; resulting vane voltages have been referenced to the $\mathrm{Kil}$ patrick spark criterion.

the original cholce of a $2.06 \mathrm{~K}+$ lpatrick ceslgn voltage level is rather conservative.

\section{Concluston}

Our studies on an RFQ with large fleld errors conftrm this linac structure's abllity to produce usable beam in the face of very adverse condtions. In addition, the experimental results provide conflrmation of our ablitty to predict this structure's pel.foimance with our present computer codes.

This RFO is at present being modifled to elimlnate most tuning difficuitles encountered with its very long structure. In addition to minor mechanical changes, vanes with machining errors are belng remachined to eliminate such errors, and dipole shorting rings modeled after those used on the Berkeluy RF? are being installed. With these changes we anticlpate operation at destan parameters.

\section{References}

1. J. E. Stovall, K. R. Cranda!l, an. R. W. Hamim, "Perforinance Charactertstics of a 42b-MHz RFO IInac," Proc. 6th Conf. on Applications oi Accelerators in iesearch and Industry, Denton, Texas, November 3-5, 1980, IFFE: Tians. Nucl. Sct. 28, n. 1500 ( 1981$)$.

?. J. Motter, F. O. Purser, and F. J. Ilumphry, "Radio-l requency (Ouadrupole Tuning Experlence," Proc. loniz Particle Accel. Conf., Santa Fe, Mew MexIco. March 71-7.3, 19.13 (19113).

3. P. W. Alltson, H. V. Sinith, Jr., and J, D. Sherman, "ll- Ior Source Research at Los Alamos, "Proc. ?nd Int. Symp), on the Product I.sn and Neutrallzation of Neqrit Ivo Hydroupll Iors and Banins, Upton, New York, October b-10, 1980), Brookhaven National laboratory reporl HNI-!jijon, p. $1 / 1$ (|q|I|).

A. K. R. lirandall, R. II, Stokns, and I. I, Wanclere,

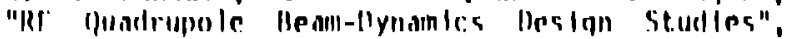
Proc. 1079 I.Inrar Arcelorentor Conf. Montauk. New Yerk, Sentember 10-11, 19/1, Hrookhaven National inouratory repurl HNI.-!li.34. p. 20!s (I) (1)

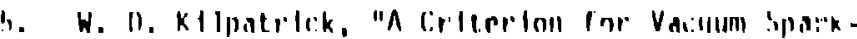

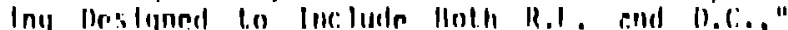
Hev. irl. Inil., Vol. H, n. Hen (|l|,|).

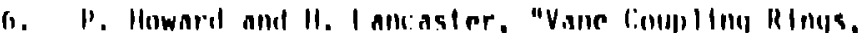

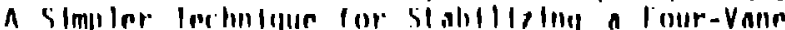

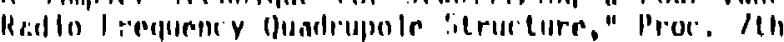

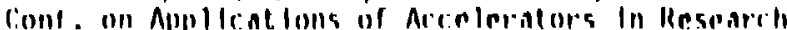
and Industiy, Inentom, Irxas, November, IoHe. 